\title{
An unproblematized truth: Foucault, biopolitics, and the making of a sociological canon
}

\section{Maurizio Meloni ${ }^{1}$ (ID}

Accepted: 7 February 2022

(c) The Author(s) 2022

\begin{abstract}
Foucault's argument that a major break occurred in the nature of power in the European Eighteenth century - an unprecedented socialization of medicine and concern for the health of bodies and populations, the birth of biopolitics-has become since the 1990s a dominant narrative among sociologists but is rarely if ever scrutinized in its premises. This article problematizes Foucault's periodization about the politics of health and the way its story has been solidified into an uncritical account. Building on novel historiographic work, it challenges the modernist bias of histories of biopolitics and public health and considers an earlier and more plural history of collective practices of health of which the story told by Foucault is just one important episode. Finally, it discusses the implications of this revised model for wider sociological debates on the link between modernity, health and the body.
\end{abstract}

Keywords Biopolitics · Foucault · Medicalization · History $\cdot$ Premodern/modern · Public health

\section{Introduction: problematizing Foucault's politics of time}

Nearly four decades after his untimely death, Michel Foucault remains an unavoidable reference for debates in social theory and health. Building on archival research and genealogical analysis, Foucault has produced a sophisticated wealth of texts on the politics and history of health-from the body in Pagan Antiquity to the modern medical gaze. This material has generated a rich conceptual repertoire-governmentality, biopolitics, power as primarily productive-that has been fruitfully operationalized in case studies of medical knowledge, from 'psy' experts to dentistry and genetic risk (Armstrong 1985; Rose 1985; Nettleton 1992; Novas and Rose 2000).

Maurizio Meloni

Maurizio.meloni@deakin.edu.au

https://www.deakin.edu.au/about-deakin/people/maurizio-meloni

1 Alfred Deakin Institute for Citizenship and Globalisation, Deakin University, Geelong Waurn Ponds Campus, Geelong, VIC 3216, Australia 
Perhaps more substantially, this vocabulary has offered for the first time a clear theoretical focus for sociology of health bringing it closer to mainstream debates on modernity, power, and rationalization (Turner 1997). This is, of course, not to say that Foucault or Foucauldian ideas have persuaded everyone in the discipline (for instance, Gilleard and Higgs 2014), or that there are not major critiques of his concepts, even among people significantly inspired by his work. Foucault himself as any genuine thinker, is quite a mobile target, with recognized shifts in his ongoing and unfinished work (Nye 2003). In sociology and social theory, much of the debate and criticisms have focused on Foucault's view of power, his elusive notion of resistance, and his avoidance of normative debates. However one area has received insufficient attention: the peculiar politics of time (Davis 2012, 2019), chronology, and periodization that undergird Foucault's narrative about the "emergence" of a politics of health in modern Europe (Foucault 1978, 1980, 2007, 2014). There is an obvious tension in Foucault's work. On one side, Foucault is par excellence a "sceptic" (Veyne 1997), the demystifier of great, teleological narratives in health and the body. On the other side, however, Foucault and his concepts stand today for a rather noticeable narrative (and perhaps even a 'grand' one): that a major break occurred in the nature of power at some point in the North-European Eighteenth-century, the "birth" of biopolitics (Foucault 1978, 2007, 2008); and it is only then that a genuine socialization of medicine with its normalizing effects became a key feature in the operations of power (Foucault 1980, 2014). It is important to remember here that, albeit stated often in epochal terms - the "entry of life into history (....) into the sphere of political techniques" (1978, pp. 141-142)—Foucault's announcement of a modern biopolitical break did not really go really beyond a number working hypotheses. While he gave a thorough treatment of the eighteenth-century break in clinical practice (2012 [1963]), the best sources to pin down a possible genealogy for the sometimes elusive concept of biopolitics are the three Brazilian conferences in Río de Janeiro (October-November 1974: Foucault 1994a, b, c), where for the first time the term bio-political was used (in an adjectival and hyphenated form, Foucault 1994b, p. 210), ${ }^{1}$ and the two versions of his The Politics of Health in the eighteenth century (original 1976 and 1979: available in English, respectively, since 1980 and 2014). It is exactly at this mid-1970s group of texts that recognized Foucauldians such as Paul Rabinow and Nikolas Rose have looked to track the genealogy of biopolitics, a concept that, as they correctly point out, "was not trans-historical or metaphoric, but precisely grounded in historical, or genealogical, analysis" (2006, p. 199).

While it is fair to recognize that biopolitics has a wider application than a certain break in the politics of health, it is true as Rabinow and Rose claim that this concept cannot be abstracted from the empirical context and specific analyses that led Foucault to portray a new power of fostering life increasingly supplementing, since the eighteenth century, the old classical framework of sovereignty. Following Rabinow's

\footnotetext{
1 The three Brazilian conferences at the Instituto de Medicina Social in Rio were part of a wider series of Foucauldian interventions in Brazil from 1965 to 1976. For their specific political and cultural context in response to some of the assumptions see Rodrigues (2016)
} 
and Rose's suggestion, in this article I look again at the conferences, interviews, and sources that ground Foucault's claim that biopolitics is

the attempt, starting from the eighteenth century, to rationalize the problems posed to governmental practice by phenomena characteristic of a set of living beings forming a population: health, hygiene, birthrate, life expectancy, race. (Foucault 2008, p. 317).

This article proceeds in three parts. First I offer an overview of Foucault's positions on the politics of health and its history, secondly I analyse how his thesis has been secured as an unproblematized narrative in sociological writings and finally, by reviewing recent historiographic work, I draw attention to an alternative history of biopolitics. In outlining this latter point, I propose an earlier, more plural and multiscalar perspective. This revised model is not only chronologically more accurate but is also relevant for contemporary debates in social theory and health on the politics of health and populations.

\section{ONE: Foucault's argument for an eighteenth century birth of biopolitics}

\section{Timeframe and scales of analysis: a "big bang" view of biopolitics}

According to Foucault, biopolitics was born in the eighteenth century at the confluence of a number of social (shifting role of family, concern for vitality of workforce), political (governmentalization of state function) and epistemological changes (mercantilism, statistics, birth of the human sciences, biology), In particular, the demographic transition of the European eighteenth century in Europe gives a strong justification to the exceptionality of the moment selected by Foucault. As B. S. Turner claims:

The nexus of knowledge/power was thus initially an effect of demographic changes, particularly the pressure of populations on systems of government and regulation from the eighteenth century (1997, p. XV)

In response to the "great eighteenth-century demographic upswing in Western Europe" (Foucault 1980, p. 171), a new politics of health took place through new concepts like population, and the governmentalization of the administrative apparatuses of Northern-European states like Prussia, Austria, France and England (1994b, pp. 211-212). Governing this complexity resulted in a shift in the nature of power, from a repressive to a productive modality (2007). As Foucault writes:

Taking a longer perspective, one could say that from the heart of the Middle Ages power traditionally exercised two great functions: that of war and peace (...) and that of the arbitration of lawsuits and punishments of crimes (...). To these functions were added - from the end of the Middle Ages those of the maintenance of order and the organization of the enrichment. 
Now, in the eighteenth century, we find a further function emerging, that of the disposition of society as a milieu of physical well-being, health, and optimal longevity. (1980, p. 170, my italics).

In the 1979 version of the Politics of Health, we find the addition of a new paragraph to address the power implications of "the appearance of a politics of health".

[This new politics] must also be related to a much more general process: that which made the "well-being" of society one of the essential objectives of political power. [...]... "A legitimate king is one whose aim is the public good." Certainly, this is a traditional idea, but in the seventeenth and eighteenth centuries it took on a much denser and much more precise meaning than it had in the past. (...) [2014 (1979): 116, my italics]

To implement this shift toward societal wellbeing "as one of the essential objectives of political power", different power apparatuses such as police:

are called upon to take charge of 'bodies', not simply so as to exact blood service from them or levy dues, but to help and if necessary constrain them to ensure their own good health. The imperative of health: at once the duty of each and the objective of all. (1980, pp. 169-170)

\section{Interventions: no politicization of medical knowledge before the eighteenth century}

One of the consequences of this shift is that traditional medical notions (such as regimen, diet etc.) are now transferred from the individual to the collective scale:

The old notion of a [medical] regime understood as both a rule to live by and a form of preventative medicine tended to expand and to become the collective "regime" of a population taken as a whole [...] This hygiene, as a regime for the health of populations, implies on the part of medicine a certain number of authoritarian interventions and controls (2014 [1979], p. 120)

And a few lines later:

Medicine as a general technique of health, much more than as treatment of illnesses and an art of cures, took a more and more important place in the administrative structures and in that machinery of power which continued to expand and to assert itself through the course of the eighteenth century. (ibid)

A related claim is that the only visible measure of public health before this major eighteenth-century shift (i.e. quarantine), however, important in anticipating disciplinary forms, lacked the characteristics of productivity and permanency of future measures of regulation of people's bodies that will take place only after the eighteenth century (1977). Before then, "medicine understood and exercised as a "service' was never anything but one element of 'relief'” (2014 [1979], pp. 114). 


\section{Norms: from health to normality through modern medicine}

If biopolitics is a shift from sovereignty and the law to "techniques of normalization [that] develop from and below a system of law" (2007, p. 84), how is medical history and its practices related to this shift? Here, a similar periodizing scheme is found originally a decade before in the Birth of the Clinic, and further developed in the second Brazilian conference (1994b). The argument is that:

up to the end of the eighteenth century medicine related much more to health than to normality (2012 [1963], p. 35)

Before the eighteenth century, medical practice

did not begin by analysing a 'regular' functioning of the organism and go on to seek where it had deviated (....) it referred, rather, to qualities of vigour, suppleness, and fluidity, which were lost in illness and which it was the task of medicine to restore. To this extent, medical practice could accord an important place to regimen and diet, in short, to a whole rule of life and nutrition that the subject imposed upon himself. This privileged relation between medicine and health involved the possibility of being one's own physician. Nineteenth-century medicine, on the other hand, was regulated more in accordance with normality than with health (....) (ibid: my italics).

This claim has significant resonances with Canguilhem's work that posits that ancient medicine imitates the redressing power of nature and hence favour a "wait-and-see approach" in which everyone can be their own doctor and it is nature (nor the doctor or the patient) in the last resort to do its curative job: vis medicatrix naturae (2012a). It deeply shaped Foucault's two later volumes on Pagan Antiquity: here medical advice is part of a moment of an idealized formation "of oneself as a subject", an independent space through which "you can discover better than any doctor what suits your constitution" (1985, p. 108).

According to this story, the modern authoritarian power of medicine is instead imbued with new social demands that not just redefine health and illness but erodes the power of sovereignty and law toward a society of norm and technologies of normalisation (2007: 83 and ff.). State control and licensing of the medical profession is again referred back to the eighteenth century citing the specific cases of France and Germany (1994b).

\section{TWO: the solidification of Foucault's claims in later sociological writings}

In order to offer a concise overview of the positioning of sociologists of medicine with regard to the Foucauldian narrative of an eighteenth century break in the politics of health, I have searched (March, 2021) for articles that include in their text-title-abstract 'Foucault' and 'biopolitics' in six high-impact factor medical 
journals: (a) Sociology of Health and Illness; (b) Social Science and Medicine; (c) Health Sociology Review (previously Annual Review of Health Social Science); (d) Social Theory and Health; (e) Health, Risk and Society; and (f): Journal of Health and Social Behavior. I have also occasionally referred to articles in other journals (Theory, Culture and Society, Journal of Medical Humanities, Frontiers in Sociology [Medical Sociology]) for their relevance to the above search. ${ }^{2}$ To this first corpus, I have added highly cited books and chapters in English language by sociologists of biomedicine who cite Foucault's "Politics of health in the eighteenth century" (mostly from the 1980 English version). The specific focus on medical sociology depends on two factors: (a) biopolitics is mostly diffracted in this article through the history and politics of health and medicine; and (b) the academic affiliation of most of the core mediators of Foucauldian knowledge into sociology. It is important to clarify that I am not interested here in a quantitative analysis nor personal critique. In a STS language, I have looked at the processes of stabilization and solidification (Latour and Woolgar 1979, p. 105) of claims into a canon through citation patterns and rhetoric framings by a fairly consistent group of authors that can be considered core mediators of Foucault's legacy into English-speaking sociology. As observed in different contexts, the securing of such tropes is less about individual opinions, than the overall apparatus of reviewers, editors, commentators, and their role in flagging, stopping or leaving unnoticed various claims and statements (Hemmings 2005). Spanning from the mid-1980s to the present, my analysis has identified two distinctive phases:

1) 1985-2001: Foucault is cited as establishing a major break in the nature of power since the eighteenth century; the cogency of the argument is mostly based on Foucault's authority and sources

For a first generation of sociologists, Foucault's 'phenomenal' legacy is cited as having established that the eighteenth century:

was the first time in history that power concentrated on life instead of just deciding about death; biological and political existence started to interface with each other (Gastaldo in Petersen and Bunton 1997, p 114, my italics).

In the first review-essay in Sociology of Health and Illness on Foucault, David Armstrong (1985) claims that Foucault

has pointed out that one feature of the operation of power from the end of the eighteenth century when the individual 'emerged from below the threshold of description' was biopolitics: the problem of managing populations. (1985, p. 115 , my italics)

Sarah Nettleton (1988), in the same journal, claims similarly that Foucault

\footnotetext{
2 The search returned 142 items, including book review articles. Search was then filtered to assure that articles discussed or criticized Foucault's periodizing narrative: this returned 15 articles, all referenced and discussed in the following section, alongside relevant chapters and books.
} 
described how after the eighteenth century the body had become the source and object of knowledge; the body became known: understood, trained and controlled; the 'population' being regulated through a system of surveillance ensured a normalisation of all bodies. (1988, p. 161 my italics)

There is an evident bifurcation in the narratives of the first Foucauldians. For a first group, the emerging narrative is one of a post-Enlightenment spread of controlling authorities on individual bodies and populations. Petersen for instance simply reports with no comments Foucault's claim that

the development of public health measures in the eighteenth century [was] but one of numerous and diverse techniques for achieving the subjugation of bodies and the control of populations (1993, p. 119, my italics)

On a more specific matter-dentistry-Nettleton claims that

[since the mid nineteenth century] the mouth became a vulnerable boundary of particular significance; it became the orifice through which disease could enter and consequently it had to be rigorously guarded (1988, p.156, my italics)

A different trope, one that does not lament increasing subjection but emphasizes novelty, comes instead from Nikolas Rose's work. In a highly cited article in Theory Culture and Society Rose (2001) takes the eighteenth-century break as foundational to posit a uniqueness of the modern condition when it comes to a "vital politics':

Foucault's thesis, as is well known, was that, in Western societies at least, we lived in a 'biopolitical' age. Since the $18^{\text {th }}$ century, political power has no longer been exercised through the stark choice of allowing life or giving death. Political authorities, in alliance with many others, have taken on the task of the management of life in the name of the well-being of the population as a vital order and of each of its living subjects. Politics now addresses the vital processes of human existence (....). (2001, p. 1, my italics)

In a chapter written a few years earlier (Jones and Porter 1994, here citing from 2002 edition), Rose interestingly presents 'medicine since its inception, [as] (...) a profoundly "social" science' which has played 'a formative role in the invention of the social' (2002, p. 54-55). Given that 'medicine' well predates the eighteenth century, the claim seems open to the possibility of a longer view about the politics of health. However, Rose's overall argument does not disrupt the Foucauldian chronology, rather it confirms that

medicine has been bound up with the ways in which, since the end of the eighteenth century, the very idea of society has been brought into existence and acquired a density and a form. (p. 54., my italics except the latter)

Rose goes on to claim that the new vitalist character of politics can be seen in the responses across the urban space, 
to the epidemics that ravaged European cities in the eighteenth and nineteenth century [and] struck terror into the inhabitants of the towns and those who would exercise government over them. (2002, p. 55, my italics)

It is at this historical juncture that, 'the town became a multifaceted apparatus for fighting disease and securing health'. This peculiar choice of eighteenth-century epidemics (rather than fourteenth century for instance) allows Rose to make a connection between biopolitics, medicine's liberal vocation, and the 'enlightened dream' of 'the healthy body - the healthy city' (ibid.).

Deborah Lupton has also been consistent in citing Foucault's eighteenthcentury article (2012) and establishing a connection between biopolitics, Enlightenment and modern forms of political legitimacy. However, her highly cited The Imperative of Health (1995; the title is a reference to the above Foucault's passage in the Politics of Health) is unique in the context of the literature reviewed, because it shows at least some interest in sources other than Foucault for premodern public health. Lupton, for instance, recognizes that many of the measures that Foucault attributed to the eighteenth century existed elsewhere in Italian cities a few centuries before (1995, p. 18). It is not clear, however, if 'Italy' was an exception for the time, a teleological 'precursor' of modernity, or actually just part of a wider archipelago of health intervention. She also recognizes elsewhere that 'much of medieval writing (...) reveals an obsession with illness' (2012, p. 82, citing medieval historian Katharine Park). One might wonder if this means also predating a social interest in the quest for health, but the claim is then taken as a statement about the objective high morbidity and mortality of medieval centuries. Finally, she notes also importantly that the alleged eighteenth-century break might actually be part of a self-serving myth of Victorian historiography:

despite the discourse of reform articulated by members of the public health movement [in the nineteenth century], the measures they introduced differed little from those adopted by the Italian states between the fourteenth and seventeenth centuries (1995, pp. 29-30, my italics)

However, whether the above sentence could potentially lead to a problematization of Foucault's periodizing work, any possible revision is neutralized by the claim that

(...) instead of the emergency measures of epidemic control typical of medieval Europe, the emphasis in the mid-nineteenth century shifted to the application of a permanent set of regulations and measures to prevent the spread of disease. (ibid., p. 30, my italics)

It is not only the 'emergency' vs. 'systematic' dichotomy that reinforces the premodern/modern gap, but also the 'religious' vs. 'secular one': i.e., that before the modern break,

while factors such as the climate, diet and odours were believed to play an important part in causing disease, the ultimate cause was deemed to be God's will: disease was God's punishment for the sins of humankind. (1995, p. 21, my italics) 
2) 2001-Present: The narrative has stabilized into an unproblematized truth based not only on Foucault's authority and through newly available College de Frances courses $(2007,2008)$, but on that of the first generation of core mediators of Foucault's knowledge

Foucault's eighteenth-century narrative obviously left a major impression on the first generations of Foucauldian mediators. Several factors might have played a role, including a peculiar resonance between the author's position and the general cultural situation of the audience (see Baert 2015 for Sartre); dissatisfaction toward existing frameworks in sociology and social theory; the capacity to demarcate new area of research such as the sociology and social theory of the body. It is possible that other more subjective factors have played a role in this legitimation, including the seductive allure of French theory particularly for Anglophone scholars (see Lamont, 1987) or the "performatively constructed social authority" of rising intellectual stars like Foucault (Bartmanski, 2012, p. 431).

If one looks instead at a second generation of writings what emerges is a shifting of the term into an intellectual trademark that defines a certain affiliation or positioning of the speaker but possesses little explanatory power. While the 18th break in the politics of health is embraced only by a limited group of authors and that more than three quarters of all articles in my search do not reflect any periodizing template - that is they remain agnostic to Foucault's claim of a historical shift in the politics of health-it is true on the other side that there is no existing critique or problematization of Foucault's empirical foundations to his eighteenth century birth of biopolitics argument. ${ }^{3}$ The eighteenth-century break narrative-that modern power shifted then as the biological characters of the species became part of political strategies (Fraser et al. 2019, p. 112) - is invariably repeated as a now canonical argument relying both on Foucault's authority and the work of the first generation of Foucauldian mediators that, in a circular way, confirms Foucault's chronologies (see Nadesan 2010, chapter 2). Foucault is for instance referenced as having put on the agenda a now.

classic debate [that] charts the emergence of 'social medicine' in Europe as radicalising medicine from pre-modern era medicine (....) 'Social medicine' antiquated pre-modern understandings of medicine by emphasising the concept that medicine is applicable to and a concern over the entire collective of every individual of a given society (Boulton 2020, p. 244, my italics; similar examples in: Martin et al. 2013, p. 82; Thualagant 2016, p. 201; Shih et al. 2017, p. 52)

Other sources are occasionally cited to support Foucault's argument, but mostly authors already working within a Foucauldian perspective, such as Katz for gerontology or Hacking for statistics (Pickard 2014; McBride 2017). Four decades after his work, Foucault is still portrayed as a heretic, whose work has been

\footnotetext{
3 The only critique to Foucauldian chronologies in health in my search is Gilleard and Higgs (2014) that, however, do not criticize the eighteenth century break suggested by Foucault but the specific point of an epidemiological transition in the twentieth century supported by a first-generation Foucauldian like sociologist David Armstrong.
} 
useful in challenging the status quo, by deconstruction of the self-evidence of social institutions, and their knowledge and practice base. (Newnham, 2014, p. 256)

However, this never pushes this or other authors to a self-reflective interrogation about Foucault's theory as a new form of status quo, where alternative sources are silenced or remain unaddressed.

Following the simplifications of the first generations of Foucauldians, the image of the past is also conveyed in simplistic terms and performs a rhetorical function to make modernity unique: either medieval power depended only on exclusionary means when it comes to public health (Pereira and Scott 2017, p. 72), or was heavily centralized while it is networked and distributed in modernity (Fries 2008).

The debate seems to have reached an "epistemic closure". A recent well-cited article on medicalization reports the state-of-the art knowledge in the area:

The historical literature seems to agree on two arguments in this regard. One argument is that initial forms of medical social control date back to the late seventeenth century as part of the collectivization of everyday life events in which the functioning of nation-states exposed the human body to growing normalization, normativization, and moralization (e.g., the rise of sanitary, preventive medicine) (Correia 2017, my italics).

Only cited sources to support the above claim are again Foucault, and in a circular way the first generation of Foucaldians (namely Armstrong and Lupton). The complexity that Foucault had tried to introduce looking at how old ideas or practices were reframed within a new political rationality (for instance, 1977) seems lost.

\section{THREE: Revising the Foucauldian narrative}

\section{Uniqueness of the eighteenth century?}

In the writings, conferences and collective work mentioned by Rabinow and Rose, it is unquestionable that Foucault's choice of examples lends naturally to the eighteenth and early nineteenth century as turning point in the politics of health. Among other things, Foucault cites the first hydrographic plan in Paris (1742), the establishment of the French Academy of Medicine (1820), George Rosen's work on the rise of a medical police (Medizinischepolizei) since the late eighteenth century in Austria and Germany, Morel's Dissertation on children disease in Lille (1812) as evidence for this shift. To justify this temporal framework, both Foucault and Foucauldians have referred to the demographic transition of the eighteenth century in Europe as "context for the emergence of modern forms of management, discipline and government" (Turner 2007, p. XV). However, such view does not do justice to the complex, non-linear way in which urban and demographic patterns of growth have occurred prior to the "eighteenth century break", and particularly for Eurasia in the High Middle Ages, when the ratio of urban population and its related commercial networks (at least before the Black Death) reached figures and a dynamism that in some cases remained unexceeded well into the Industrial Revolution (Goldstone 
2002; Geltner 2019a; Lopez 1976; Cesaretti et al. 2016). For this reason, rather than thinking in terms of the rise of the West, Goldstone suggests the term "efflorescences" to map premodern periods of sudden and sharp urban and commercial growth over global history (2002).

It is also debatable whether the premodern healthscape was patchy and episodic, or based merely on exclusionary means, as suggested by Foucault in his analysis of quarantine (1977). A new wave of studies on premodern healthscaping practices claim differently (Rawcliffe 2013; Geltner 2019a): particularly at the urban scale, the politics of health was stable, capillary, and operationalized through the establishment of a legislative corpus for health and environmental regulation, town doctors, and in some cases, boards of medical experts (Weeda and Rawcliffe 2019; McVaugh, 2002). Local authorities sought the cooperation of existing professional associations (guilds, confraternities) but often appointed specific figures such as municipal officials and ward constables. An often-discussed example for a more-than-European history of global biopolitics is the medieval market inspector, whose origins are in the twelfth-century Islamicate with the name of muhtasib (Buckley, 1999). The diffusion of the muhtasib and its equivalents in Europe through the Islamic government of Spain exemplifies the practical and symbolic importance of the medieval urban market, the stomach of the city-body, as an experimental site for "governments' disciplining gaze" (Geltner 2019a). Police governance, too, largely predates the eighteenth century and did not have just repressive functions. As in the case of Bologna's Office of "Crowns and Arms" (from 1286), urban police contributed to "promoting the health, productivity, and general well-being of the community", by appealing to the ideal of the common good (bonum commune or utilitas publica) (Roberts 2019, p. 7) which was ubiquitous in Latin Christendom well before the eighteenth century.

There are a few significant points to make about this new historiographic trend which I reviewed elsewhere (Meloni 2021) that have more specific relevance for social theory and health. I will focus on four related areas here:

(a) While the direct intervention of doctors in shaping health and environmental measures is a matter of debate for historians and depends very much on local contexts, there is no doubt these measures were motivated by an Hippocratic-Galenic understanding of disease as generated mostly by corrupted air and intense smells from dirty streets, rotten food, or animal carcasses (Geltner 2019b). Given miasmatic theory (pathogenic power of corrupt air) and widespread views of corporeal permeability (infection through the nose, open eyes, or pores), the medieval individual and civic body was in a state of constant concern and "frenzied zeal" over preventing possible sources of contamination and infection (Cipolla 2004).

(b) The dominant argument that medieval governments implemented public health measures only as an emergency response to epidemics, and particularly the Black Death (1347-1351), is not correct either. Certainly, in some cases, the bubonic plague worked as a catalyst for strengthening health measures or making medical advice literature (so called consilia) more popular and widely read. However, several of these measures and urban statutes of preventive health did predate - by several decades - the Black Death (Geltner 2020). Even more importantly, historians have questioned the same distinction between epidemic and endemic disease as a post-bacteriology understanding that does not capture the complexity of 
medieval public health where often fighting corrupted air or quarantining infected bodies should be seen in a logical continuum (Crawshaw 2016).

(c) A neat distinction between Godliness and Healthiness to describe premodern public health practices is also problematic. The combination of morality, spirituality and health agendas emerges powerfully in the premodern and early modern literature thus blurring distinctions that make little sense for the time. Abigail Agresta's work on environmental sanitation in Valencia (1300-1500) is a good example of how boundaries between religious, environmental and health interventions for the salut of the civic body are difficult to establish and these different categories of public responses were actually often self-reinforcing (2016).

(d) While authoritarian health intervention (promoted by local governors and civic authorities) was certainly a reality, historians have noted how these measures would have been void if they did not "rely in part on the active engagement and compliance of the population", which is one of the key tenets of the novelty of biopolitics argument (Rawcliffe 2013). Several authors have described this process of "medicalization" from below in medieval times, from intense demand for medical advice and literature, to petitions and complaints about deviant public health behaviour addressed to local health commissioners. Premodern and early modern quarantine itself represented a complex landscape, where often top-down intervention was negotiated among local stakeholders, as in the case of sixteenth-century Sevilla (Bowers 2007).

\section{Impolitical nature of premodern medicine?}

Unrecognized by Foucault' writings on Pagan Antiquity, premodern (humoral) medicine was not just used at the individual level as a technology of the self but directly at the collective level too. The language of humours was employed, for instance, in racializing discussions about group differences by philosophers and geographers alike or, in military treatises to describe how to recruit troops from certain climates, maintain the vitality of the military force through food and exercise, or defeat populations having hot or cold blood (Meloni 2020, 2021). It was used also by architects, urban planners, military engineers, water managers, road officials to build fortifications, cities, theatres, harbours, hospitals, and monasteries (Geltner 2019a, b). Planning for these sites had to follow key recommendation of Hippocratic-Galenic knowledge about the salubriousness of the place and materials (orientation to sun and winds, ventilation, lighting fixtures, proximity to swamps, sanitation of waters). Archaeological evidence supports the ubiquitous presence of these prophylactic insights, and their social or public nature, for instance in the construction of mines and military camps (Coomans and Geltner 2013). This newly emerging area of research is particularly important to pluralize histories of healthcare because it shows that the politicization of medicine and group health didn't happen only at the urban level (the city as forerunner of the modern State) but also in non-sedentary contexts: rural miners, itinerant armies, and mariners, all premodern 'populations' to which principles of prophylactic care were applied following Galenic insights and whose development often preceded the urban politics of health (Geltner 2019b, 2021; Geltner and Weeda 2021). 
The dynamism of Galenic medicine can be seen also at a more wider cultural level. While medieval scholarship has traditionally focused on the organicistic metaphor of the civic body (Nederman 2013), recent scholarship has convincingly shown how the peculiar Galenic model of humoral balance and body equilibrium decisively reframed this organicistic language (Kaye 2014). The ubiquity of humoral language has been documented cross-culturally in political debates on the quest for the perfect polity and the wellbeing of the populace, from the thirteenth to the fifteenth century in areas as different as medieval and early modern Persianate, Mughal and Ottoman traditions and imperial ideologies, and Florentine political thought (Syros 2013). Finally, it is important to consider the wider social context where these debates about health, humoral balance, and bodily equilibrium occurred. Since the so-called rebirth of medicine in medieval Europe, mostly via Arabic works and translations, attention to health, disease and longevity was, if not imperative, definitely an extremely important phenomenon in what has been called the Global Middle Ages (Holmes and Standen 2018). It was, in Foucauldian terms, a 'problematic'. For lack of space, it is worth citing here what is considered a key window into medieval life: the collection of documents describing the Jewish community of Genizah in Old Cairo (Fustat). The wealth of references to medical substances, personal hygiene, baths, perfumes, spices, methods of preparation of potions and pills, evidences a point that historians have made now numerous times for premodern life: i.e. that "health was an important and fundamental issue in the past as it is today_perhaps even more" (Lev and Amar 2008, p. 11; see Goitein 1993). Other historians have covered the widespread interest in medical advice (consilia) after the Black Death, and later the extraordinary surge of interest in vernacular books on health, eating right, and longevity in the Renaissance (Cavallo and Storey 2013; Gilleard 2013) alongside a pervasive culture of medical prevention and health care in domestic lifestyles and ordinary homes (Cavallo and Storey 2017; Albala 2002).

\section{No 'normality' in premodern medicine?}

The last point to address in Foucault's narrative is probably the most contentious and still open to debate: the claim that health not normality is what is at stake in medical thinking and practices until the eighteenth century. While it is true that normality as a term did not belong to medicine until modernity (Canguilhem 2012a and $2012 \mathrm{~b}$ ), this cannot be taken as an in-principle objection to the notion that actual practices and concepts of medicine before modern times might have an intense normalizing dimension and ideological function. It is a recognized possibility, as historians of the longue durée have pointed out, that "content may exist before the noun that expresses it" (Bethencourt 2013, p. 3, Febvre 1962).

Historians of medicine for instance have remarked how deeply moralizing is the humoral language when it comes to dietetics, exercise or control of emotions (Grant 2000). Galenic medicine is deeply informed by views of imbalance, the technical term is here $d y s$ crasia. If health is a good mixing (eukrasia), there are at least eight combinations of bad mixing that need to be corrected to bring the body into a "normal" or even "optimal" state. Vivian Nutton, the most important authority on ancient medicine in England, has no trouble in attributing ideas of normality to Galen. The ancient doctor, according to Galen: 
should also be able to learn about the normal lifestyle of the patient, for this indicated not only the humoral and qualitative balance or imbalance, but also the habits, likes and dislikes that most affected the body. Habit, on which Galen wrote a short treatise, might determine reaction to certain drugs or foods, and a doctor's ignorance of the normal lifestyle of his patient might lead to disaster (Nutton 2020, p. 33, my italics).

Historian Joel Kaye thus translates Galen's “quantification of qualitative imbalance and cure" in the widely read medieval treatise the Tegni:

In order to restore health, we must find a medicine that is proportional to the magnitude of the ill-balance (proportionale magnitudini discrasie) of the complexion, so that if, for example, a body deviates from its normal nature by a figure of ten to the hot and by a figure of seven to the dry, then the healthful cause in such cases must be ten to the cold and seven to the moist (Kaye, 2014: 163 , my italics)

Rather than making of medical normality the brainchild of the Enlightenment, it would be probably safer to diffract different iterations of normality and normalization across history. For instance (without being exhaustive), a religious or organicistic normality based on highly symbolic ideas of purity and impurity; a dynamic Galenic normality based on models of balance and equalization that stimulated the emergence of a language of proportion, ratio, and probability contributing to population thought after the thirteenth century (Kaye 2014; see also Biller 2000); and a modern biomedical normality based on statistical thinking and population average, that had greater importance after the nineteenth century and culminated with the construction of modern states and their imperial expansion across the globe. ${ }^{4}$ This historical complexity, however, cannot be taken for an argument that bodies before the eighteenth century were not normalized through a whole range of experts including healers or doctors. A history of the premodern world shows that medical practices were no less normalizing than contemporary ones. One spectacular case is therapeutic bloodletting, either via a sharp blade or medical leeches (Hirudo medicinalis), probably the most widespread cross-cultural form of premodern medical practice since at least Egypt (3500 BCE), present in India, the Arab world, the Roman empire, the Middle-Ages and beyond. It was widely discussed and defended by Galen himself and for obvious reasons: given that the humoralist body is based on a processual ontology of flows and fluxes, health depends on a constant attention to obstruction to these flows (Meloni 2019). Any type of evacuation (including blood and vomit), purging, or opening of pores, would work for the goal. Historian K. Codell Carter has argued that bloodletting was so effective, sought after and ubiquitously prescribed until the nineteenth century, because it acted as a system "for reinforcing social and moral norms"- - either excesses or defects in food or lifestyle. Bloodletting was hence the figurative punishment for illness (humoral imbalance or, later, "inflammability") as a deviation from social norms, and a ritual of purification

\footnotetext{
${ }^{4}$ I thank both reviewers for their suggestion in this section.
}

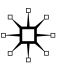


to bring patients back to normal behaviour (2012). It is difficult to deny that notions associated to bloodletting, such as eliminating "vicious humours", "starving a fever" or drawing "tainted" blood from a patient lacked a deep normalizing meaning. Political references to purging the cities from vicious humours (Rawcliffe 2013) also relied on a similar imagination.

\section{CONCLUSION: Foucault's legacy and the will not to know}

Postcolonial criticism about Foucault's blindness to extra-European spaces and his tendency to universalize from concepts and chronologies that are at best Northern European is far from new (Stoler 1995; Spivak 2000). Regardless of his indisputable merits as a genealogist of modern power, it is undeniable that only by disrupting and displacing Foucault's Eurocentric assumptions has a rich analysis of colonial and postcolonial governmentality emerged (Legg 2007; Stoler 1995). By putting imperial notions of race at the center, several works have suggested that the first forms of "biopolitical experimentations" have actually taken shape or have been fully deployed only through colonial encounters or in colonial settings (Kaplan 1995; Mbembe 2003; Redfield 2005). More importantly for the goal of this article, it was not through modern medical advancements in France or England, but drawing from ancient medical thinking, particularly Hippocratic-Galenic conceptions of body permeability (humoralism), that a racial biopolitics of colonial populations has occurred, for instance, in the Americas since the sixteenth century (López Beltrán 2007, Corcoran-Tadd and Pezzarossi 2018). To further contribute to a provincialization and displacement of Foucauldian biopolitics, this article has reconsidered not just what sociologist would call the "epistemic exclusion" (Go 2020; Bhambra 2014) of its spatial alterity (the colonies), but also of its temporal Other, the Middle Ages. That, from the teleological angle of winning Northern European modernity, there are possible symmetries between the process of "medievalization" of oriental and indigenous cultures by European colonizers and the projection of colonial clichés onto the medieval past is far from surprising for medieval historians (Dagenais and Greer 2000; Davis and Altschul 2009). Historically, the foundation of medieval studies overlaps with colonial and imperialist processes in the second half of the nineteenth century: in a process that obviously intertwines with the Orientalist framework described by Said (1979), the Middle Ages was then built as an easy repository for a number of stereotypes that have boosted European colonial self-consciousness and its sense of a unique modernity (Davis 2012; Ganim 2016).

Even considering the proverbial retreat of sociologists into the present (Elias 1987), it is somehow disconcerting the ease with which, after Foucault's tentative analysis, Foucauldian scholarship has repeated such modernist framework that literally erases centuries of global practices of care for the collective body in urban and non-urban spaces before the advent of Northern European modernity. The premodern historical literature I discussed in this article has now been available in English 
for a decade or more: it is hence not a case of "unknowability". Besides disciplinary silos effects that have hindered transfer of knowledge, there are also forms of confirmation bias and "strategic ignorance" (McGoey 2020) further legitimated by the iconic status of an academic star like Foucault. However, the sole reliance on Foucault as a gatekeeper to our historical past has ultimately simplified his critical insights into a modernist myth about the birth of biopolitics after the eighteenth century and culminating with our present neoliberal societies. This is a view that, far from being revolutionary, perfectly aligns with mainstream histories of sociology or public health.

Just because Foucault has undeniably given us a model that is good to think with, this does not rule out that alternative models could be, if not better, at least more suitable to highlight areas that have remain unnoticed or to correct some of the oversimplifications of Foucauldian scholarship. While it is true that there is still little empirical work on the biopolitical and medicalizing effects of premodern and holistic medical systems (Lowenberg and Davis 1994), a longer and more plural history of biopolitics may be more productive on a number of counts. It can avoid the stagelike simplifications of thinking in terms of teleological succession from sovereign power to discipline to biopolitics (as Foucault himself cautioned 2007); by decoupling biopolitics and normalization from modern medicine it can open up a field of enquiry not just about past (and present) intense biopolitical effects of holistic medical systems and practices but also about contemporary forms of hybridization of Western biomedicine and alternative or traditional non-Western medicine (see for Ayurveda: Subramaniam 2019; Rooney 2020; Meloni 2021); it may lend further complexity to a multilayered history of medicalization (Ballard and Elston 2005; Busfield 2017), suggesting that the modern rise of experts did not colonize otherwise pristine bodies. It can, finally, suggest humility in some of the epochal claims we have seen in the discipline in the last few decades: notions that the pursuit or 'imperative of health' is an unprecedented feature and value of late modernity (Lupton 1995); that the human body was "fabricated" at the end of the eighteenth century (Armstrong 1985), as if other cultures did not also display different forms of fabrication and control of bodies and populations; that advanced capitalist societies are the first 'somatic society' that have established a direct relationship between bodies and selfhood (Rose 2001, see on the intense somaticism of premodern humoralism my 2019). Qualifying and contextualizing all of these claims may help undermine forms of epistemic ethnocentrism that insulate practices and concepts in 'advanced liberal societies' from the rest of global history, past and present.

Funding Open Access funding enabled and organized by CAUL and its Member Institutions. Research Funded by the Australian Research Council Future Fellowship Award FT180100240.

Open Access This article is licensed under a Creative Commons Attribution 4.0 International License, which permits use, sharing, adaptation, distribution and reproduction in any medium or format, as long as you give appropriate credit to the original author(s) and the source, provide a link to the Creative Commons licence, and indicate if changes were made. The images or other third party material in this article are included in the article's Creative Commons licence, unless indicated otherwise in a credit line to the material. If material is not included in the article's Creative Commons licence and your intended use is 
not permitted by statutory regulation or exceeds the permitted use, you will need to obtain permission directly from the copyright holder. To view a copy of this licence, visit http://creativecommons.org/licen ses/by/4.0/.

\section{References}

Agresta, A. 2016. Many waters: An environmental history of Valencia, 1300-1500. New Haven: Yale University.

Albala, K. 2002. Eating right in the Renaissance. Berkeley: University of California Press.

Armstrong, D. 1985. Review essay: The subject and the social in medicine: An appreciation of Michel Foucault. Sociology of Health and Illness 7 (1): 108-117.

Baert, P. 2015. The existentialist moment. New York: Wiley.

Ballard, K., and M. Elston. 2005. Medicalisation: A multi-dimensional concept. Social Theory \& Health 3 (3): 228-241.

Bartmanski, D. 2012. How to become an iconic social thinker: The intellectual pursuits of Malinowski and Foucault. European Journal of Social Theory 15 (4): 427-453.

Bethencourt, F. 2013. Racisms: from the crusades to the twentieth century. Princeton, NJ: Princeton University Press.

Bhambra, G.K. 2014. Connected sociologies. London: Bloomsbury Publishing.

Biller, P. 2000. The measure of multitude: Population in medieval thought. Oxford: Oxford University Press on Demand.

Boulton, R., et al. 2020. The cultural politics of 'Implementation Science.' Journal of Medical Humanities 41 (3): 379-394.

Bowers, K. 2007. Balancing individual and communal needs: plague and public health in early modern Seville. Bulletin of the History of Medicine 81: 335-358.

Buckley, R. 1999. The book of the Islamic market inspector. Oxford: Oxford University Press.

Busfield, J. 2017. The concept of medicalisation reassessed. Sociology of Health \& Illness 39 (5): $759-777$.

Canguilhem, G. 2012a. On the normal and the pathological. Berlin: Springer.

Canguilhem, G. 2012b. Writings on medicine. New York: Fordham University Press.

Carter, K.C. 2012. The decline of therapeutic bloodletting and the collapse of traditional medicine. Piscataway: Transaction Publishers.

Cavallo, S., and T. Storey. 2013. Healthy living in late Renaissance Italy. Oxford: Oxford University Press.

Cavallo, S., and T. Storey. 2017. Conserving health in early modern culture: Bodies and environments in Italy and England. Manchester: Manchester University Press.

Cesaretti, R., Lobo, J., Bettencourt, L.M., Ortman, S.G., \& Smith, M.E. 2016. Population-area relationship for Medieval European cities. PloS one 11 (10): e0162678.

Coomans, J., and G. Geltner. 2013. On the street and in the bathhouse. Anuario De Estudios Medievales 43 (1): 53-82.

Cipolla, C.M. 2004. Public health and the medical profession in the renaissance. Cambridge: Cambridge University Press.

Corcoran-Tadd, N., and G. Pezzarossi. 2018. Between the South Sea and the mountainous ridges: Biopolitical assemblages in the Spanish colonial Americas. Post-Medieval Archaeology 52 (1): 84-101.

Correia, T. 2017. Revisiting medicalization: A critique of the assumptions of what counts as medical knowledge. Frontiers in Sociology. https://doi.org/10.3389/fsoc.2017.00014/full.

Crawshaw, J. 2016. Plague hospitals: Public health for the city in early modern Venice. Milton Park: Routledge.

Dagenais, J., and M.R. Greer. 2000. Decolonizing the middle ages: Introduction. Journal of Medieval and Early Modern Studies 30 (3): 431-448.

Davis, K. 2012. Periodization and sovereignty: How ideas of feudalism and secularization govern the politics of time. Philadelphia: University of Pennsylvania Press.

Davis, K. 2019. From periodization to the autoimmune secular state. Griffith Law Review 27 (4): $411-425$. 
Davis, K., and N. Altschul. 2009. Medievalisms in the postcolonial world: The idea of "the Middle Ages" outside Europe. Baltimore: Johns Hopkins University Press.

Elias, N. 1987. The retreat of sociologists into the present. Theory, Culture \& Society 4 (2-3): 223-247.

Febvre, L. 1962. Pour une histoire à part entière. Paris: Editions de l'Ecole des hautes études en sciences sociales.

Foucault, M. 1977. Discipline and Punish. Birth of the prison. New York: Pantheon Books.

Foucault, M. 1978 [1976]. The history of sexuality: An introduction. London: Allen Lane.

Foucault, M. 1980 [1976]. The politics of health in the eighteenth century. In Power/knowledge. Selected interviews and other writings, 1972-1977, ed. C. Gordon 166-182.

Foucault, M. 1985. The history of sexuality, vol. 2: The use of pleasure. New York: Random House.

Foucault, M. 1994a. Crise de la medecine ou crise de l' antimedecine? In Dits et écrits 1954-1988, eds. D. Defert, F. Ewald, and J. Lagrange, volume 3rd: 1976-1979, 40-58. Paris: Gallimard.

Foucault, M. 1994b. La naissance de la medecine sociale In Dits et écrits 1954-1988, eds. D. Defert, F. Ewald, and J. Lagrange, volume 3rd: 1976-1979, 207-228. Paris: Gallimard.

Foucault, M. 1994c. L'incorporation de l'hôpital dans la technologie modern, In Dits et écrits 19541988, eds. D. Defert, F. Ewald, and J. Lagrange, volume 3rd: 1976-1979, 508-521. Paris: Gallimard.

Foucault, M. 2007. Security, territory, population. New York: Palgrave Macmillan.

Foucault, M. 2008. The birth of biopolitics. New York: Palgrave Macmillan.

Foucault, M. 2012 [1963]. The birth of the clinic. Routledge.

Foucault, M. 2014 [1979]. The politics of health in the eighteenth century. Foucault Studies, 113-127.

Fraser, A., et al. 2019. Biopolitics, space and hospital reconfiguration. Social Science \& Medicine 230: 111-121.

Fries, C.J. 2008. Governing the health of the hybrid self: Integrative medicine, neoliberalism, and the shifting biopolitics of subjectivity. Health Sociology Review 17 (4): 353-367.

Ganim, J. 2016. Medievalism and Orientalism. Berlin: Springer.

Gastaldo, D. 1997. Is health education good for you? Re-thinking health education through the concept of bio-power. In Foucault, health and medicine, eds. A.R. Petersen, and R. Bunton, 113-133. London: Psychology Press.

Geltner, G. 2019a. Roads to health: Infrastructure and urban wellbeing in later medieval Italy. University of Pennsylvania Press.

Geltner, G. 2019b. In the camp and on the march: Military manuals as sources for studying Premodern Public Health. Medical History 63 (1): 44-60.

Geltner, G. 2020. The path to Pistoia: Urban hygiene before the black death. Past \& Present 246 (1): 3-33.

Geltner, G. 2021. Kinetic health: Ecologies and mobilities of prevention in Europe, c. 1100-1600. Mobilities, $1-16$.

Geltner, G., and C. Weeda. 2021. Underground and over the sea: More community prophylactics in Europe, 1100-1600. Journal of the History of Medicine and Allied Sciences 76 (2): 123-146.

Gilleard, C. 2013. Renaissance treatises on "successful ageing." Ageing and Society 33 (2): 189.

Gilleard, C., and P. Higgs. 2014. Revisionist or simply wrong? A response to Armstrong's article on chronic illness. Sociology of Health \& Illness 36 (7): 1111-1115.

Go J (2020) Race, Empire, and Epistemic Exclusion: Or the Structures of Sociological Thought. Sociological Theory

Goitein, S.D. 1993. A mediterranean society, vol. 2 and 5. Berkeley, CA: University California Press.

Goldstone, J. 2002. Efflorescences and economic growth in world history. Journal of World History 2002: 323-389.

Grant, M. 2000. Galen on food and diet. New York: Routledge.

Hemmings, C. 2005. Telling feminist stories. Feminist Theory 6 (2): 115-139.

Holmes, C., and N. Standen. 2018. Introduction: Towards a global middle ages. Past \& Present 238 (suppl_13): 1-44.

Kaplan, M. 1995. Panopticon in Poona: An essay on Foucault and colonialism. Cultural Anthropology 10 (1): 85-98.

Kaye, J. 2014. A history of balance, 1250-1375. Cambridge: Cambridge University Press.

Lamont, M. 1987. How to become a dominant French philosopher: The case of Jacques Derrida. American Journal of Sociology 93 (3): 584-622.

Legg S. 2007. Beyond the European province: Foucault and postcolonialism. Space, knowledge and power: Foucault and geography, 265-289.

Lev, E., and Z. Amar. 2008. Practical materia medica of the medieval Eastern Mediterranean according to the Cairo Genizah. Leiden: Brill. 
Lopez, R.S. 1976. The commercial revolution of the Middle Ages, 950-1350. Cambridge University Press.

López Beltrán, C. 2007. Hippocratic bodies. Temperament and Castas in Spanish America (1570-1820). Journal of Spanish Cultural Studies 8 (2): 253-289.

Lowenberg, J.S., and F. Davis. 1994. Beyond medicalisation-demedicalisation: The case of holistic health. Sociology of Health \& Illness 16 (5): 579-599.

Lupton, D. 1995. The imperative of health: Public health and the regulated body. Thousand Oaks: Sage.

Lupton, D. 2012. Medicine as culture: Illness, disease and the body. Thousand Oaks: Sage.

Martin, G., et al. 2013. Between surveillance and subjectification: Professionals and the governance of quality and patient safety in English hospitals. Social Science \& Medicine 99: 80-88.

Mbembe, A. 2003. Necropolitics. Public Culture 15 (1): 11-40.

McBride, R.S. 2017. On the advancement of therapeutic penality. Sociology of Health \& Illness 39 (7): $1258-1272$.

McGoey, L. 2020. Micro-ignorance and macro-ignorance in the social sciences. Social Research: An International Quarterly 87 (1): 197-217.

McVaugh, M. 2002. Medicine before the Plague: Practitioners and their patients in the Crown of Aragon, 1285-1345. Cambridge: Cambridge University Press.

Meloni, M. 2019. Impressionable biologies: From the archaeology of plasticity to the sociology of epigenetics. Routledge.

Meloni, M. 2020. Porous bodies: Environmental biopower and the politics of life in Ancient Rome. Theory, Culture \& Society 38 (3): 91-115.

Meloni, M. 2021. The politics of environments before the environment: Biopolitics in the longue durée. Studies in History and Philosophy of Science Part A 88: 334-344.

Nadesan, M. 2010. Governmentality, biopower, and everyday life. London: Routledge.

Nederman, C.J. 2013. Medieval political theory: A reader: The quest for the body politic 1100-1400. London: Routledge.

Nettleton, S. 1988. Protecting a vulnerable margin: Towards an analysis of how the mouth came to be separated from the body. Sociology of Health \& Illness 10 (2): 156-169.

Nettleton, S. 1992. Power, pain, and dentistry. London: Open University Press.

Newnham, E. 2014. Birth control: Power/knowledge in the politics of birth. Health Sociology Review 23 (3): 254-268.

Novas, C., and N. Rose. 2000. Genetic risk and the birth of the somatic individual. Economy and Society 29 (4): 485-513.

Nutton, V. 2020. Galen: A thinking doctor in imperial Rome. London: Routledge.

Nye, R.A. 2003. The evolution of the concept of medicalization in the late twentieth century. Journal of the History of the Behavioral Sciences 39 (2): 115-129.

Pereira, M., and J. Scott. 2017. Harm reduction and the ethics of drug use: Contemporary techniques of selfgovernance. Health Sociology Review 26 (1): 69-83.

Petersen, A.R. 1993. Re-Defining the subject?: The influence of Foucault on the sociology of health and illness. Annual Review of Health Social Science 3 (1): 119-131.

Petersen, A.R., and R. Bunton, eds. 1997. Foucault, health and medicine. London: Psychology Press.

Pickard, S. 2014. Frail bodies: Geriatric medicine and the constitution of the fourth age. Sociology of Health \& Illness 36 (4): 549-563.

Rabinow, P., and N. Rose. 2006. Biopower today. BioSocieties 1 (2): 195-217.

Rawcliffe, C. 2013. Urban Bodies: Communal health in late medieval English towns and cities. Rochester: Boydell \& Brewer Ltd.

Redfield, P. 2005. Foucault in the tropics: Displacing the panopticon. In Anthropologies of modernity: Foucault, governmentality, and life politics, ed. J.X. Inda, 50-82. New York: Wiley.

Roberts, G. 2019. Police power in the Italian communes, 1228-1326. Amsterdam: Amsterdam University Press.

Rodrigues, H.B.C. 2016. Ensaios sobre Michel Foucault no Brasil. Presença, efeitos, ressonâncias. Rio de Janeiro: Lamparina.

Rooney, N. 2020. Ayurveda, preconception, biological plasticity, and the re-conception of a nation. Somatosphere. http://somatosphere.net/2020/ayurveda-epigenetics-india.html/

Rose, N. 1985. The psychological complex: Psychology, politics and society in England, 1869-1939. London: Routledge Kegan \& Paul.

Rose, N. 2001. The politics of life itself. Theory, Culture \& Society 18 (6): 1-30.

Rose, N. 2002. Medicine, history and the present. In Reassessing Foucault, 58-82. Routledge, London 
Said, E. 1979. Orientalism. Vintage.

Shih, P., et al. 2017. Pastoral power in HIV prevention: Converging rationalities of care in Christian and medical practices in Papua New Guinea. Social Science \& Medicine 193: 51-58.

Spivak, G.C. 2000. Can the subaltern speak? In Postcolonialism: Critical concepts in literary and cultural studies, ed. D. Brydon, 1427-1477. London: Routledge.

Stoler, A.L. 1995. Race and the education of desire: Foucault's history of sexuality and the colonial order of things. Durham: Duke University Press.

Subramaniam, B. 2019. Holy science: The biopolitics of Hindu nationalism. Seattle: University of Washington Press.

Syros, V. 2013. Galenic medicine and social stability in early modern Florence and the Islamic empires. Journal of Early Modern History 17 (2): 161-213.

Thualagant, N. 2016. Body management and the quest for performative health. Social Theory \& Health 14(2)

Turner, B.S. 1997. Foreword. In Foucault, health and medicine, eds. Petersen and Bunton. Psychology Press, IX-XXII

Veyne, P. 1997. Foucault revolutionizes history. In Foucault and his interlocutors, ed. A. Davidson, 146-182. University of Chicago Press.

Weeda, C., Rawcliffe, C. (eds) .2019. Policing the urban environment in premodern Europe. Amsterdam University Press, Amsterdam

Publisher's Note Springer Nature remains neutral with regard to jurisdictional claims in published maps and institutional affiliations. 